\title{
Przezklatkowa ocena echokardiograficzna serca trójprzedsionkowego lewego z wykorzystaniem obrazowania trójwymiarowego
}

\author{
Transthoracic echocardiographic assessment of cor triatriatum sinister \\ with three dimensional imaging
}

\author{
Ewelina Kowalczyk, Jarosław D. Kasprzak, Paulina Wejner-Mik, Piotr Lipiec \\ Katedra i Klinika Kardiologii Uniwersytetu Medycznego w Łodzi
}

\begin{abstract}
Pacjent, w wieku 85 lat, został przyjęty do kliniki kardiologii z powodu pogorszenia tolerancji wysiłku fizycznego i zawrotów głowy. W wywiadzie stwierdzono przewlekłą niewydolność serca na podłożu choroby wieńcowej (stan po 3 zawałach serca) i niedoczynność tarczycy. W badaniu przedmiotowym odnotowano niewielkie obrzęki kończyn dolnych, pojedyncze trzeszczenia nad polami płucnymi oraz nieznacznie powiększoną wątrobę. W badaniach laboratoryjnych zwracała uwagę wartość NT-proBNP $2114 \mathrm{pg} / \mathrm{ml}$. W wykonanym przezklatkowym badaniu echokardiograficznym uwidoczniono rozległe zaburzenia kurczliwości lewej komory z frakcją wyrzutową 28\%, przy prawidłowej funkcji skurczowej prawej komory oraz zastawki serca bez istotnych zmian organicznych. Ponadto w świetle lewego przedsionka uwidoczniono membranę bez gradientu napływowego (serce trójprzedsionkowe, cor triatriatum) z polem otworu w membranie ocenianym na $3,1 \mathrm{~cm}^{2}$.
\end{abstract}

Dyskusja

Serce trójprzedsionkowe stanowi zaledwie 0,1-0,4\% wszystkich wad wrodzonych serca [1], a postać izolowana (bez towarzyszących innych wad serca) występuje jeszcze rzadziej. W wadzie tej obserwuje się dodatkowy podział jednego z przedsionków przez błonę włóknisto-mięśniową. W przypadku lewego przedsionka (jak w prezentowanym przypadku) jest to pozostałość obecnej w życiu płodowym pierwotnej żyły płucnej. Postać błony tworzącej przegrode (całkowita, niezupełna lub fenestrowana otworami) oraz jej rozmiar, kształt, grubość i położenie są zmienne osobniczo. Wiek, w którym rozpoznaje się wadę, objawy kliniczne, przebieg, rokowanie i decyzje o leczeniu chirurgicznym zależą od wielkości otworu i ewentualnych towarzyszących innych wad serca. Przy zachowanym, ale istotnie zwężonym przepływie między proksymalną a dystalną częścią lewego przedsionka objawy mogą naśladować zwężenie zastawki mitralnej. Dochodzi wówczas do wzrostu ciśnienia w komorze proksymalnej, które przekłada się na wzrost ciśnienia w krążeniu płucnym i zwiększenia obciążenia następczego prawej komory. Leczenie polega na operacyjnym wycięciu membrany dzielącej lewy przedsionek. Z kolei duży otwór między proksymalną a dystalną częścią przedsionka, bez istotnego gradientu, może przebiegać bezobjawowo i nie wymagać leczenia operacyjnego.

Kluczową rolę w rozpoznawaniu wady oraz kwalifikacji do leczenia ma przezklatkowe badanie echokardiograficzne. W projekcjach koniuszkowych widoczna jest linowa struktura przebiegająca w lewym przedsionku powyżej zastawki mitralnej i uszka lewego przedsionka (ryc. 1A, B) [2]. Wykorzystując sondę 3D, można wyraźnie uwidocznić kształt i rozmiar otworu łączącego proksymalną i dystalną część lewego przedsionka (ryc. 1E). Dodatkowo badanie przy użyciu kolorowego doplera pomaga w lokalizacji i ocenie stopnia komunikacji obu jam (ryc. 1C), a za pomocą doplera pulsacyjnego można oszacować maksymalny i średni gradient ciśnień (ryc. 1D) [2]. Przyjmuje się, że prędkość powyżej $2 \mathrm{~m} / \mathrm{s}$ odpowiada ciężkiemu zwężeniu [3]. W przypadku trudności w uzyskaniu optymalnego okna akustycznego zaleca się wykonanie echokardiograficznego badania przezprzełykowego [2].

\section{Piśmiennictwo}

1. Jegier W, Gibbons JE, Wiglesworth FW. Cortriatriatum: clinical, hemodynamic and pathological studies surgical correction in early life. Pediatrics. 1963; 31: 255-267, indexed in Pubmed: 14010411.

2. Jha AK, Makhija N. Cor triatriatum: a review. Semin Cardiothorac Vasc Anesth. 2017; 21(2): 178-185, doi: 10.1177/1089253216680495, indexed in Pubmed: 27913770.
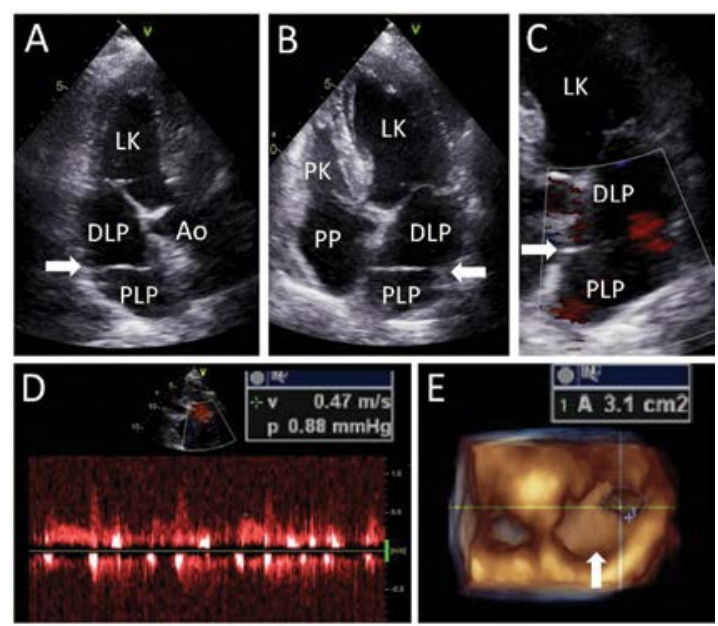

Rycina 1A-E. Serce trójprzedsionkowe lewe w projekcji trójjamowej (A) oraz czterojamowej (B) bez gradientu między proksymalną i dystalną częścią lewego przedsionka (C); ocena przepływu przez otwór z użyciem doplera pulsacyjnego (D); membrana dzieląca lewy przedsionek (widok z części proksymalnej w kierunku części dystalnej - biała strzałka) $z$ uwidocznionym pojedynczym otworem o polu powierzchni $3,1 \mathrm{~cm}^{2}(\mathrm{E})$; Ao - aorta; LK - lewa komora; DLP - jama dystalna lewego przedsionka; PLP - jama proksymalna lewego przedsionka; PK - prawa komora; PP - prawy przedsionek

3. Houston A, Hillis S, Lilley $\mathrm{S}$, et al. Echocardiography in adult congenital heart disease. Heart. 1998; 80(Suppl 1): S12-S26, doi: 10.1136/hrt.80.2008.12s, indexed in Pubmed: 10078071.

Adres do korespondencji: lek. Ewelina Kowalczyk, Katedra i Klinika Kardiologii, Uniwersytet Medyczny w Łodzi, Szpital Biegańskiego, ul. Kniaziewicza 1/5, 91-347 Łódź, tel./faks 4265399 09, e-mail: kowalczyk@o2.pl 